\title{
FIRST RECORD OF THE INVASIVE SNAIL Melanoides tuberculatus (GASTROPODA: PROSOBRANCHIA: THIARIDAE) IN THE PARANÃ RIVER BASIN, GO, BRAZIL
}

\author{
ROCHA-MIRANDA, F. and MARTINS-SILVA, M. J. \\ Universidade de Brasília, Departamento de Zoologia, Campus Universitário Darcy Ribeiro, \\ ICC, Ala Sul, CEP 70910-900, Brasília, DF, Brazil \\ Correspondence to: Fabio Miranda da Rocha, Laboratório de Bentos, Departamento de Zoologia, IB, \\ Universidade Brasília, CEP 70910-900, Brasília, DF, Brazil, e-mail: ecofabio@ yahoo.com.br \\ Received April 11, 2005 - Accepted May 5, 2005 - Distributed November 1, 2006 \\ (With 3 figures)
}

\begin{abstract}
The Thiarid snail Melanoides tuberculatus (Müller, 1774), native to Asia and East Africa was recorded for the first time in the Paranã River basin, Goiás State. There is no evidence concerning introduction vectors but aquarium releases is the most probable vector. Specimens were collected at three different water bodies after twenty-seven rivers were investigated. The possible spread of this species to other habitats and potential effects on native thermal water communities are discussed.
\end{abstract}

Keywords: Mollusca, Thiaridae, Melanoides tuberculatus, invasive species, brazilian cerrado.

\section{RESUMO}

Primeiro registro do gastrópode africano invasor Melanoides tuberculatus (Gastropoda: Prosobranchia: Thiaridae) na Bacia do Rio Paranã, GO, Brasil

O gastrópode Thiaridae Melanoides tuberculatus (Müller, 1774), nativo da Ásia e do Leste Africano, é registrado pela primeira vez na Bacia Hidrográfica do Rio Paranã (Estado de Goiás). Não se conhecem os vetores de introdução da espécie, mas o setor de aquariofilia foi apontado por alguns moradores locais como a mais provável causa. Os espécimes foram coletados em três corpos d'água depois de serem investigados vinte e sete rios e lagoas. A possibilidade de dispersão dessa espécie para outros habitats e os efeitos potenciais dessa introdução sobre a comunidade nativa são discutidos no artigo.

Palavras-chave: Mollusca, Thiaridae, Melanoides tuberculatus, espécie invasora, cerrado brasileiro.

\section{INTRODUCTION}

Melanoides tuberculatus Müller 1774 (Gastropoda: Prosobranchia: Thiaridae) originates from Asia and East Africa and has established wild populations widely throughout the tropics (Pointer, 1999). Regions that it has invaded include North America (Murray, 1964), South America (Pointier et al., 1994; De Marco, 1999) and French Polynesia (Pointier \& Marquet, 1990). In Brazil, the first record of M. tuberculatus was in Santos, São Paulo State (Vaz et al., 1986) and nowadays these invasive aquatic snails have been reported in the states of Minas Gerais (Carvalho, 1986; Silva et al., 1994;
De Marco, 1999), Paraíba (Paz et al., 1995), Rio de Janeiro (Thiengo et al., 1998, 2001, 2002a, 2002b; Giovanelli et al., 2003), Ceará (Mello \& Cordeiro, 1999), Paraná (Pereira, 2000) and Federal District (Monteiro \& Dias, 1980; Vieira, 1990; Garcez \& Martins-Silva, 1997; Medeiros, 1997). Fernandez et al. (2003) still report M. tuberculatus in the States of Pará, Tocantins, Piauí, Paraíba, Pernambuco, Rio Grande do Norte, Bahia, Goiás, Mato Grosso, Mato Grosso do Sul, Paraná and Santa Catarina.

Melanoides tuberculatus has received attention from many researchers in the Neotropics because of the fact that it competes with native intermediate hosts of Schistosoma mansoni 
(Schistosomiasis agent) acting as a biological control agent (Guimarães et al., 2001; Giovanelli et al., 2003); on the other hand, M. tuberculatus could be associated with exotic trematodes which affect native fish and birds, which are intermediate hosts for parasites (Brandt, 2000).

In Goiás State there is only one record of $M$. tuberculatus occurrence (Fernandez et al., 2003), but without a specific location of occurrence. Therefore, here we briefly examine new occurrences of M. tuberculatus in Goiás State - specifying the exact location of the occurrence of this invasive species in the Paranã River basin -, comments on its ecology, and discuss possible impacts of this species on Paranã's rivers and water invertebrate communities, serving as a basis for future control and eradication projects. The aim of this report is to provide a background for future control, monitoring or managing the spread of this invasive species in Goiás State.

\section{MATERIAL AND METHODS}

During a monitoring programme of macroinvertebrate fauna undertaken from 2002 to 2004, specialists from the Laboratório de Bentos at Brasília University found three sites with an exotic snail identified as Melanoides tuberculatus. All water bodies were sampled semi-quantitatively for invertebrates using a triangular kick net $(250 \mu \mathrm{m}$ mesh) and Surber nets. At each site a consistent 3 min sampling effort was used along a $30 \mathrm{~m}$ reach. Chemical factors (temperature, conductivity, dissolved oxygen, $\mathrm{pH}$ ) were recorded by taking midstream spot measurements using a multisample meter. Coverings by different substrate types (e.g., silt, sand and gravel, organic detritus) and the degree of channel shade were visually estimated at each site.

\section{STUDY AREA}

The cerrado's biome occupies an area of approximately 2 million $\mathrm{km}^{2}$ (around $23 \%$ of the national territory), distributed mainly in the Central Plateau (Furley \& Ratter, 1988). It includes dozens of Brazilian States (Goiás, Tocantins, Federal District, a part of Bahia, Ceará, Maranhão, Mato Grosso, Mato Grosso do Sul, Minas Gerais, Piauí, Rondônia and São Paulo; and some parts of Amapá, Amazonas, Pará, Roraima and Paraná states (Ribeiro \& Walter, 1998).

The predominant climate of the region, according to Köppen's classification, is "tropical savannah" with pluviometric precipitation concentrated in the summer. The rainy season starts in October and finishes in April, representing 84\% of the annual precipitation. The rainiest months are November, January and December. The interannual average precipitation varies between $1,200 \mathrm{~mm}$ and $1,700 \mathrm{~mm}$. The annual average temperature varies from 18 to $22{ }^{\circ} \mathrm{C}$. The relative humidity of air decreases from high values of $70 \%$ at the beginning of the dry season and less than $20 \%$ at the end of the period. In the hottest period (August and September), the humidity can reach $10 \%$, typical dryness of desert.

The Paranã River basin is considered a priority Conservation area in Brazilian territory. It is part of Tocantins-Araguaia hydrographic basin and is located between $2^{\circ}$ and $18^{\circ} \mathrm{S}$ and $46^{\circ}$ and $56^{\circ} \mathrm{W}$. The annual medium outflow is $10.900 \mathrm{~m}^{3} / \mathrm{s}$, the annual medium volume is $344 \mathrm{Km}^{3}$ and it has a drainage area of $767.000 \mathrm{Km}^{2}$. The Paranã river is one of the greatest rivers from the Centro-Oeste (mid-west) region flowing through Goiás, Maranhão and Pará States. Benthic macrofauna research was carried out in the Paranã River Valley when a full biological Brazilian inventory (PROBIO) of this priority Brazilian area for Conservation was compiled. In this project we collected samples from 27 rivers in the Paranã basin (Fig. 1).

\section{RESULTS}

Melanoides tuberculatus was collected from only 3 rivers out of the 27 rivers studied in the Paranã basin. The three water bodies where M. tuberculatus occurred were in the Crixás, Cana Brava and Macacos rivers.

In all of the places, M. tuberculatus only occurred in shady and human-impacted areas, usually associated to fine and coarse particulate organic matter. The Macacos River where they occurred is associated to non identified green algae.

In the Crixás River, the mean densities of M. tuberculatus were of 2 individuals $/ \mathrm{m}^{2}$ and the organisms were sparsely distributed (Fig. 2). The infestation was more intense in the Macacos 


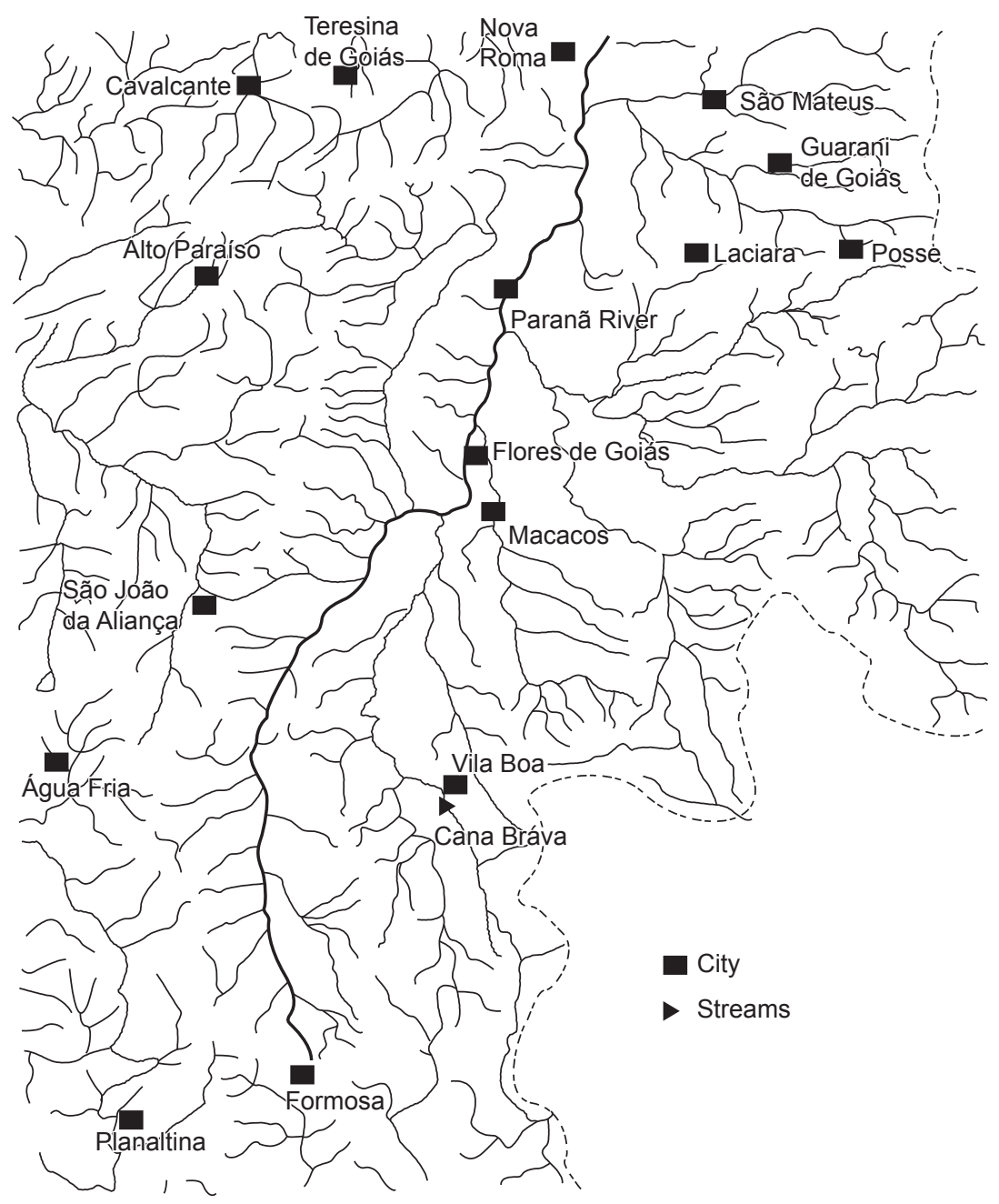

Fig. 1 - Map of the area showing the study sites, Crixás, Macacos e Cana Brava River.

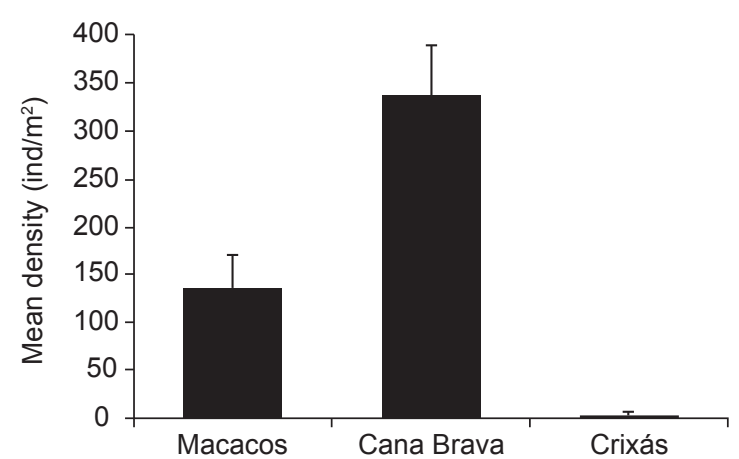

Fig. 2 - Mean density of Melanoides tuberculatus at study sites. 
and Cana Brava rivers where it reached the highest densities (Fig. 2), and no other native gastropods were found (Biomphalaria or Pomacea for example). It is clear that in both rivers the population structure is quite similar as there are a great number of young and a decreasing number of adults (Fig. 3). However, in the Cana Brava River few individuals from the class size 20-24 were found and many recruits were collected (0-4 mm), indicating that a recent reproductive event in this river must have occurred. On the other hand, in the Macacos River no recruits were found and a great number of individuals in the last class size (20-24 mm) were collected.

The shell aperture width of $M$. tuberculatus from the Cana Brava River measured between 0.3 and $6.5 \mathrm{~mm}$, with a high abundance of small individuals (Fig. 4). In the Macacos river, the distribution lies between 0.5 and 6.1 with a predominance of higher size classes (Fig. 4).

\section{DISCUSSION}

The introduced prosobranch $M$. tuberculatus is a viviparous and parthenogenetic snail that has occurred in many places around the world. This species is a successful invasive species which is recognized by its ability to colonize humanimpacted areas (Pointier et al., 1993; De Marco, 1999; Martins-Silva \& Barros, 2001).

As in other studies (Pointier et al., 1993; De Marco, 1999), the populations of M. tuberculatus that were found in the present work occurred mainly in backwaters and shady areas with fine sediment (organic detritus). All the infested places presented a certain degree of degradation. The
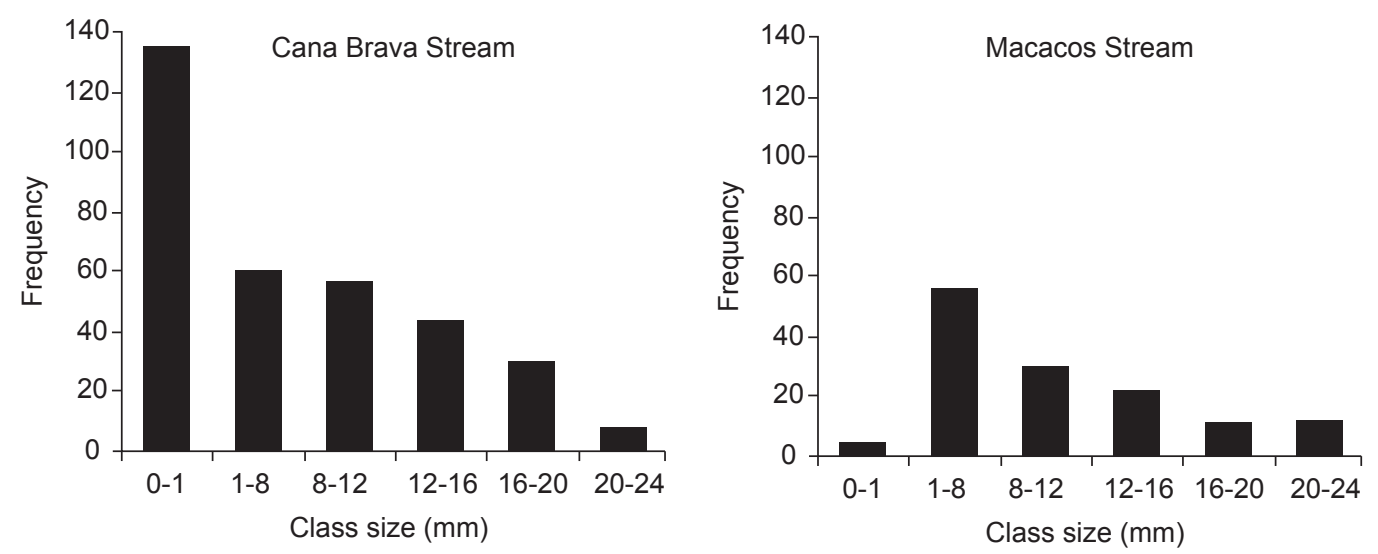

Fig. 3 - Frequency distribution of shell length of Melanoides tuberculatus colleted in Macacos and Cana Brava Streams.
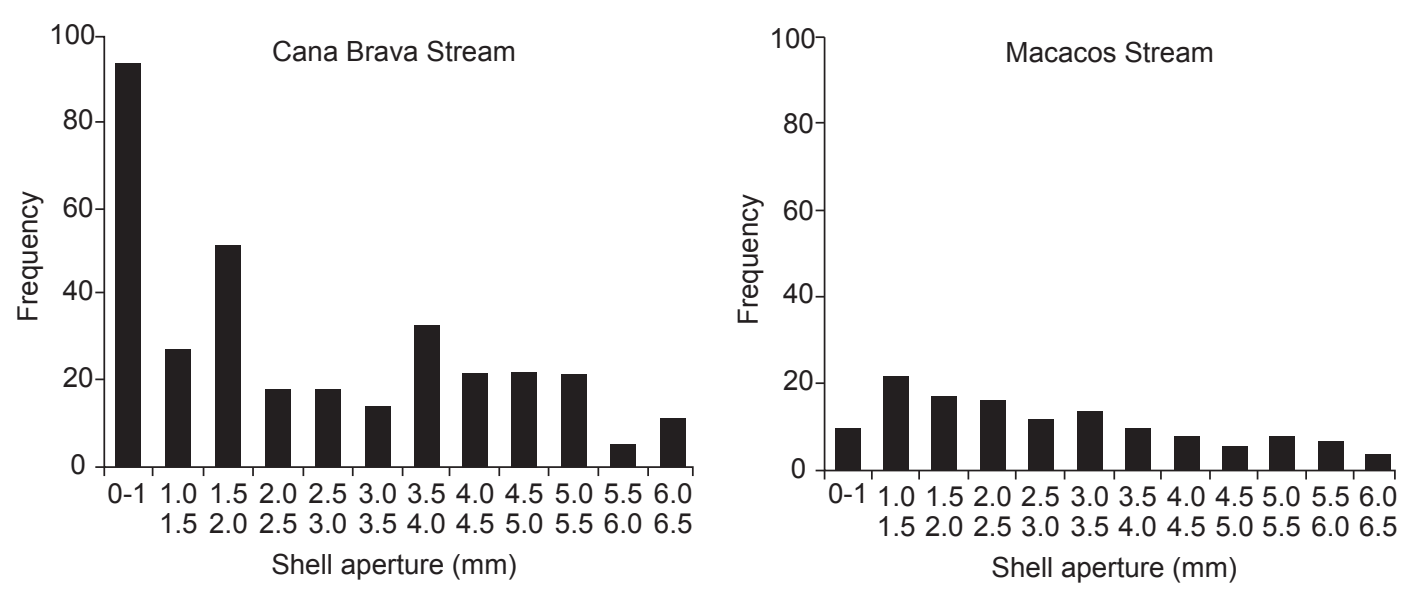

Fig. 4 - Frequency distribution of aperture width of Melanoides tuberculatus colleted in Cana Brava and Macacos streams. 
Cana Brava River, which had the highest density of infestation (334 individuals $/ \mathrm{m}^{2}$ ), is one of the most impacted rivers in the Paranã valley and has farming activities. It is clear that $M$. tuberculatus infestation is made easier in more polluted places. De Marco (1999) also found same patterns for the species distribution in Minas Gerais where the species occurred abundantly in the pier áreas, probably due to sediment properties and the absence of macrophyte cover. In the Federal District, this exotic species occurs abundantly in Lake Paranoá and in Riacho Fundo Creek (Vieira, 1990; Medeiros, 1997; Martins-Silva et al., 2001), mainly in organically polluted areas (Martins-Silva \& Barros, 2001).

It is clear that the population structure of Cana Brava and Macacos River are quite similar with a great number of young and a low number of adults (Fig. 3). However, Macacos's population seems to result from (older reproduction events, when compared with Cana Brava's population) previous infestation when compared with Cana Brava's population. This tendency occurs because in the Cana Brava River few individuals of class size 20-24 were found and many recruits were collected (0-4 mm); while in Macacos River no recruits were found a great number of older adults (20-24 mm) were collected, indicating that this population could have reproduced earlier than the Cana Brava population. Dudgeon (1986) affirms that this species can start reproduction with at least $2.8 \mathrm{~mm}$. Therefore, despite differences between these areas, around $40.41 \%$ of the Cana Brava's population and around $51.49 \%$ of the Macacos population are able to reproduce. It shows that most of both populations are able to reproduce and increase infestation degrees.

Many possible problems for native communities and sanitary questions due to M. tuberculatus invasion could be listed, however there are urgent challenges to be concerned about. Associations with pulmonate snails and parasitism by trematodes can lead to the death of native birds and mammals that live and feed on the lake. An example of an associated trematode, Centrocestus formosanus - that completes part of its lifecycle within the digestive gland of M. tuberculatus spreads heavy infections to fish and ducks in the USA (Brandt, 2000). M. tuberculatus also acts as potential intermediate hosts of Paragonimus westermani (Kerbert, 1878) and Clonorchis sinensis (Cobbold, 1875). In Brazil, few studies reported larval forms of trematodes harboring specimens of M. tuberculatus. Boaventura et al. (2002) reported Pleurolophocercus larvae (mammal and bird parasites) harboring specimens of $M$. tuberculatus from Maricá and Guapimirim. Carneiro et al. (2004) recorded Pleurolophocerca larvae (Opisthorchiidae and Cryptogonimidae) in Minas Gerais State at Pampulha's Dam for the first time.

On other hand, the biological (high reproductive capacity and adaptability to a wide range of environmental conditions) characteristics of M. tuberculatus, that make this species a good invader, seems to encourage its use in the biological control against the Schistosomiasis agent because it competes or preys on planorbid snails Biomphalaria, an intermediate host of Schistosoma mansoni (Guimarães et al., 2001; Giovanelli et al., 2003). Pointier (1993) and Pointier et al. (1989, 1991, 1993) showed the ability of this species to control and even exclude Biomphalaria in some islands of the French West Indies. Guimarães et al. (2003) reported that populations of B. glabrata and $B$. straminea decreased after the $M$. tuberculatus arrived, followed by total exclusion of the former after eight years in some places of Minas Gerais State. This natural biological control could be occurring in some places of the Paranã river basin, since in the three rivers where Melanoides occurred, there were no Biomphalaria species.

Due to the distances and the absence of M. tuberculatus in sites between Cana Brava, Crixás and Macacos in the Paranã basin, it seems that many introduction events may have occurred. However, the spread of the snail to other rivers from the Paranã basin can be made easy by aquatic birds, fishing boats, human degradation and aquarium activities, which could be the most important introduction vector due to the high number of illegal aquarium hobby farmers in this region (local inhabitant communication). All these activities often occur in this region and implementing conservation measures for this basin is urgent, otherwise the whole basin could be infested in a few years' time.

Regarding ecological importance, $M$. tuberculatus is probably already threatening the native species (Pomacea and Biomphallaria species, for example) of mollusks in the Paranã 
River basin because in all three rivers with Melanoides occurrences (Crixás, Cana Brava and Macacos) there are no native species of mollusks, which is common in other rivers of the region. These threats occur because of its ability to spread fast and colonize new habitats (natural or manmade). Finally, it can be observed that there are few ecological and taxonomic studies concerning native freshwater mollusks in Brazil and still less with impacts of infestation with $M$. tuberculatus and the expansion of this species must be totally monitored and controlled. This work will act as a background for future management programmes in conservation areas of Goiás State.

\section{REFERENCES}

BOAVENTURA, M. F., FERNANDES, M. A., TJIENGO, S. C., SILVA, R. E. \& MELO, A. L., 2002, Formas larvais de Trematoda proveninentes de gastrópodes límnicos da microrregião Rio de Janeiro, sudeste do Brasil. Lundiana 3: 45-49.

BRANDT, T., 2000, Exotic snail and associated exotic parasites affecting fishes and waterfowl in Texas. San Marcos National Fish Hatchery and Technology Center. Report Comm. Disponível em: http:// www.southwest.fws. gov/fishery/trematode.pdf. Acesso em 06/12/04.

CARNEIRO, A. C. A. V., SANTOS, V. C., SOUZA, F. B. C., MELO, A. L., 2004, Infecção natural de Melanoides tuberculatus (Muller, 1774), na represa da Pampulha, Belo Horizonte, MG. XXV Congresso Brasileiro de Zoologia, Brasília-DF

CARVALHO, O. S., 1986, Ocorrência de um tiarídeo (mollusca) no lago da Pampulha, Belo Horizonte, MG, Brasil. Revista da Sociedade Brasileira de Medicina Tropical 19: 57

DE MARCO, P. J., 1999, Invasion by the introduced aquatic snail Melanoides tuberculatus (Müller, 1774) (Gastropoda: Prosobranchia: Thiaridae) of the Rio Doce State Park, Minas Gerais, Brazil. Studies On Neotropical Fauna and Environment, Tübinge, 34: 186-189

DUDGEON, D., 1986, The life cycle, population dynamics and productivity of Melanoides tuberculatus in Hong Kong. Journal of Zoology, 208: 37-53.

FERNANDES, M. A., THIENGO, S. C. \& SIMONE, L. R. L., 2003, Distribution of the introduced freshwater snail Melanoides tuberculatus (Gastropoda: Thiaridae) in Brazil. The Nautilus, 117(3): 78-82.

FURLEY, P. A. \& RATTER, J. A., 1988, Soil resources and plant communities of the central Brazilian cerrado and their development. Journal of Biogeography, 15: 97-108.

GARCEZ, C. C. \& MARTINS-SILVA, M. J., 1997, Estudo preliminary da distribuição de moluscos gastrópodes no Lago Paranoá, Brasília,DF (Brasil). Anais do XV Encontro Brasileiro de Malacologia: 58.

GIOVANELLI, A., VIEIRA, M. V., DA SILVA, C. L. P. A. C., 2003, Apparent Competition Through Facilitation between
Melanoides tuberculatus and Biomphalaria glabrata and the Control of Schistosomiasis Memórias do Instituto Oswaldo Cruz, Rio de Janeiro, 98(3): 429-431

GUIMARÃES, C. T., SOUZA, C. P. \& SOARES, D. M., 2001, Possible Competitive Displacement of Planorbids by Melanoides tuberculatus in Minas Gerais, Brazil. Memórias do Instituto Oswaldo Cruz, Rio de Janeiro, Suppl., 96: 173-176

MARTINS-SILVA, M. J. \& BARROS, M., 2001, Occurence and Distribution of Freshwater Molluscs in the Riacho Fundo Creek Basin, Brasília, Brazil. Revista de Biologia Tropical, San José, Costa Rica, 49(3): 865-870

MARTINS-SILVA, M. J., ROCHA-MIRANDA, F., CESAR, F. B. \& OLIVEIRA, B. A., 2001, A comunidade bentônica In: Fonseca, F. O. ed. Olhares sobre o Lago Paranoá, Brasília$D F$, Editora, 485p.

MEDEIROS, M. B., 1997, Caracterização das comunidades de macroinvertebrados bentônicos da Bacia do Córrego Riacho Fundo, Brasília/DF, e uso destas como bioindicadores de qualidade de água. Master Thesis. Departamento de Ecologia Universidade de Brasília, Brazil, 82p.

MELO, H. \& CORDEIRO, L. N., 1999, Ocorrência de Melanoides tuberculata no açude Thomaz Osterne de Alencar (Umari), Crato, Ceará. XVI Encontro Brasileiro de Malacologia: 161.

MONTEIRO, W. \& M. L. F. DIAS, 1980, Distribuição de moluscos pulmonados aquáticos e identificação dos planorbídeos da Bacia do Lago Paranoá, Brasília (Mollusca: Gastropoda). Rev. Brasil. Biol., 40: 67-74

MURRAY, H. D., 1964, Tarebia granifera and Melanoides tuberculatus in Texas. American Malacological Union Inc., annual report, pp. 15-16, 1964.

PAZ, R. J., WATANABE, T., DIJEK, M. P. M. \& ABÍLIO, F. J. P., 1995, First record of Melanoides tuberculata (Muller, 1774) (Gastropoda: Prosobranchia: Tjhiaridae) in the state of Paraíba (Brazil) and its possible ecological implications. Revista Nordestina de Biologia, 10: 79-84.

PEREIRA, P. A. C., 2000, Dispersão do gastrópode invasor Melanoides tuberculata (Muller, 1774) (Mollusca: Prosobranchia: Thiaridae) no Estado do Paraná- Brasil, em biótopos lênticos e semi-lênticos. Biociências, 8: 107-114.

POINTER, J. P., 1993, The introduction of Melanoides tuberculata (Mollusca: Thiaridae) to the island of Saint Lucia (West Indies) and its role intermediate host of Schistosoma mansoni. Acta Tropica, 54: 13018.

POINTER, J. P., GUYÃRD, A. \& MOSSER, A., 1989, Biological control of Biomphalaria glabrata and B. straminea by the competitor snail Thiara tuberculata in a transmission site of schistosomiasis in Martinique, French Wset Indies. Annals of Tropical and Medical Parasotology, 83: 263-269.

POINTER, J. P., FREDERIC, M. \& MAZILLE, V., 1991, Biological control of Biomphalaria glabrata by Melanoides tuberculata on Désirade island, French West Indies. Journal of Medical and Applied Malacology, 3: 49-52.

POINTER, J. P., THALER, L., PERNOT, A. F. \& DELAY, B., 1993, Invasion of the Martinique island by the parthenogenetic snail Melanoides tuberculata and the succession of morphos. Acta Ecologica, 14: 33-42. 
POINTIER, J. P., 1999, Invading freshwater gastropods: some conflicting aspects for public health. Malacologia, Chicago, USA, 41: 403-411.

POINTIER, J. P. \& MARQUET, G., 1990, Taxonomy and distribution of freshwater molluscs of French Polynesia. Japanese Journal of Malacology, 49: 215-231.

POINTIER, J. P., INCANI, R. N., BALZAN, C., CHROSCIENCHOWSKI, P. \& PRYPCHAN, S., 1994, Invasion of the rivers of the littoral central region of Venezuela by Thiara granifera and Melanoides tuberculatus (Mollusca:Prosobranchia: Thiaridae) and the absence of Biomphalaria glabrata, snail host of Scistosoma mansoni. The Nautilus, Sanibel-USA, 107: 124-128.

RIBEIRO, J. F. \& WALTER, B. M. T., 1998, Fitofisionomias do bioma cerrado. pp. 89-167. In: Sano, S. M \& Almeida, S. P. eds. Cerrado: ambiente e flora, Brasília. Embrapa.

SILVA, R. E., MELO, A. L., PEREIRA, L. H. \& FREDERICO, L. F., 1994, Lavantamento malacológico da Bacia hidrográfica do Lago Soledade, Ouro Branco (Minas gerais). Revista do Instituto de Medicina Tropical de São Paulo, 36: 437-444.

THIENGO, S. C., FERNANDES, M. A., BOAVENTURA, M. F. F. \& STORTTI, M. A., 1998, A survey of gastropods in the microrregião serrana of Rio de Janeiro, Brazil. Memórias do Instituto Oswaldo Cruz, 93(1): 233-234.
THIENGO, S. C., FERNANDES, M. A., BOAVENTURA, M. F., GRAULT, C. E., SILVA, H. F. R., MATTOS, A. C. \& SANTOS, S. B., 2001, Freshwater snails and schistosomiasis mansoni in the State of Rio de Janeiro, Brasil: I. Metropolitan Mesoregion. Memórias do Instituto Oswaldo Cruz, 96(suppl.): 177-184.

THIENGO, S. C., FERNANDES, M. A., BOAVENTURA, M. F. F., SANTOS, S. B. \& MATTOS, A. C., 2002a, Freshwater snails and schistosomiasis mansoni in the State of Rio de Janeiro, Brasil: II. Centro Fluminense Mesorregião. Memórias do Instituto Oswaldo Cruz, 97: 621-626.

THIENGO, S. C., FERNANDES, M. A., BOAVENTURA, M. F. F., MAGAlHÃES, M. G. \& SANTOS, S. B., 2002b, Freshwater snails and schistosomiasis mansoni in the State of Rio de Janeiro, Brasil: III - Baixadas Mesoregion. Memórias do Instituto Oswaldo Cruz, 97(suppl.): 43-46.

VAZ, J. F., TELLES, M. S., CORRÊA, M. A. \& LEITE, S. P. S., 1986, Ocorrência no Brasil de Thiara (Melanoides) tuberculata (O. F. Muller, 1774) (Gastropoda: Prosobranchia), primeiro hospedeiro intermediário de Clonorchis sinensis (Cobbold, 1875) (Trematoda: Platyhelminthes). Revista de Saúne Pública, 20: 318-322.

VIEIRA, E. M. X., 1990, Aspectos estruturais da comunidade zoobentônica e os parâmetros físico-químicos do sedimento na zona litorânea no Lago Paranoá, Brasília, DF. Master Thesis. Departamento de Ecologia Universidade de Brasília, Brazil, 101p. 
